\title{
Isotope zonation in basement crustal blocks of southeastern China: Evidence for multiple terrane amalgamation
}

\author{
1 Hong Kong Geological Survey, Geotechnical Engineering Office, 101 Princess Margaret Road, Kowloon, Hong Kong. \\ 2 Department of Earth Sciences, University of Hong Kong, Pokfulam Road, Hong Kong. \\ 3 Department of Geology, University of Leicester, University Road, Leicester LE1 7RH, UK. \\ 4 Department of Earth Sciences, Nanjing University, 22 Hankou Road, Nanjing 210093, China.
}

Nd and Sr isotopic data for Mesozoic Yanshanian granites sampled across major NNE-trending faults in eastern Guangdong Province record conspicuous compositional variations in the crustal basement. Two principal crustal domains can be distinguished: Paleoproterozoic-dominated in the northwest and Mesoproterozoicdominated in the southeast. Within the Mesoproterozoic-dominated domains, thin tectonic slivers of isotopically homogeneous Paleoproterozoic crust are interspersed with narrow belts displaying mantle-derived characteristics. Combined with other published data, the Nd-Sr isotopic signatures from eastern Guangdong show that the Precambrian basement in southeastern China is largely heterogeneous and made up of a series of narrow, crustal slices.

The major domain boundaries coincide with large-scale NNE-trending strikeslip faults in the cover sequences. We postulate that these boundaries developed in the crust during the Mesoproterozoic and largely controlled the geological development of SE China throughout the Phanerozoic.

\section{Introduction}

SE China is composed of two major tectonic crustal blocks: the Yangtze Block in the north and the Cathaysia (or Huanan) Block in the south (Figure 1). The Yangtze Block is widely recognised as a cratonic shield area whereas the Cathaysia Block is made up of several mobile belts, including a broad $(400 \mathrm{~km})$ NE-trending belt of Mesozoic intrusions extending through the maritime provinces of Guangdong, Fujian and Zhejiang (Figure 1). Considerable debate has centred on the age of the basement of the Cathaysia Block, its tectonic evolution (Hsü et al., 1988, 1990; Li, 1997, and references therein), and the timing of its collision with the Yangtze Block. Although strongly overprinted by Phanerozoic tectonomagmatic activity, the
Cathaysia Block is commonly assumed to be underlain by Paleo- to Mesoproterozoic continental crust (Jahn et al., 1990; Li et al., 1992; Li, 1994; Li, 1998; Chen and Jahn, 1998). Since exposures of Precambrian crystalline rocks in southeastern China are rare, the best way to study the basement structure is through isotopic studies of granitoid rocks which preserve signatures of their source areas.

Previous isotopic investigations of Mesozoic magmatic rocks in the coastal region of SE China have demonstrated the existence in some areas of isotopic inhomogeneity in the crustal basement (Huang et al., 1986; Huang and DePaolo, 1989; Pei and Hong, 1995). In one of the few documented regional Nd-Sr studies, Huang et al. (1986) distinguished three isotopic zones within Cretaceous magmatic rocks from Fujian Province: an inland zone with ${ }^{87} \mathrm{Sr} /{ }^{86} \mathrm{Sr}_{\mathrm{i}}=0.711$ to 0.737 and $\varepsilon_{\mathrm{Nd}}(\mathrm{T})=-8.2$ to -12.2 , a central zone with ${ }^{87} \mathrm{Sr} /{ }^{86} \mathrm{Sr}_{\mathrm{i}}=0.706$ to 0.713 and $\varepsilon_{\mathrm{Nd}}(\mathrm{T})=-2.1$ to -11 , and a coastal zone with ${ }^{87} \mathrm{Sr} /{ }^{86} \mathrm{Sr}_{\mathrm{i}}=0.7058$ to 0.7073 and $\varepsilon_{\mathrm{Nd}}(\mathrm{T})=-1.7$ to -3.6. They considered that the general trend of higher $\varepsilon_{\mathrm{Nd}}$ and lower initial $\mathrm{Sr}$ ratio from the inland area to the coast could be explained by

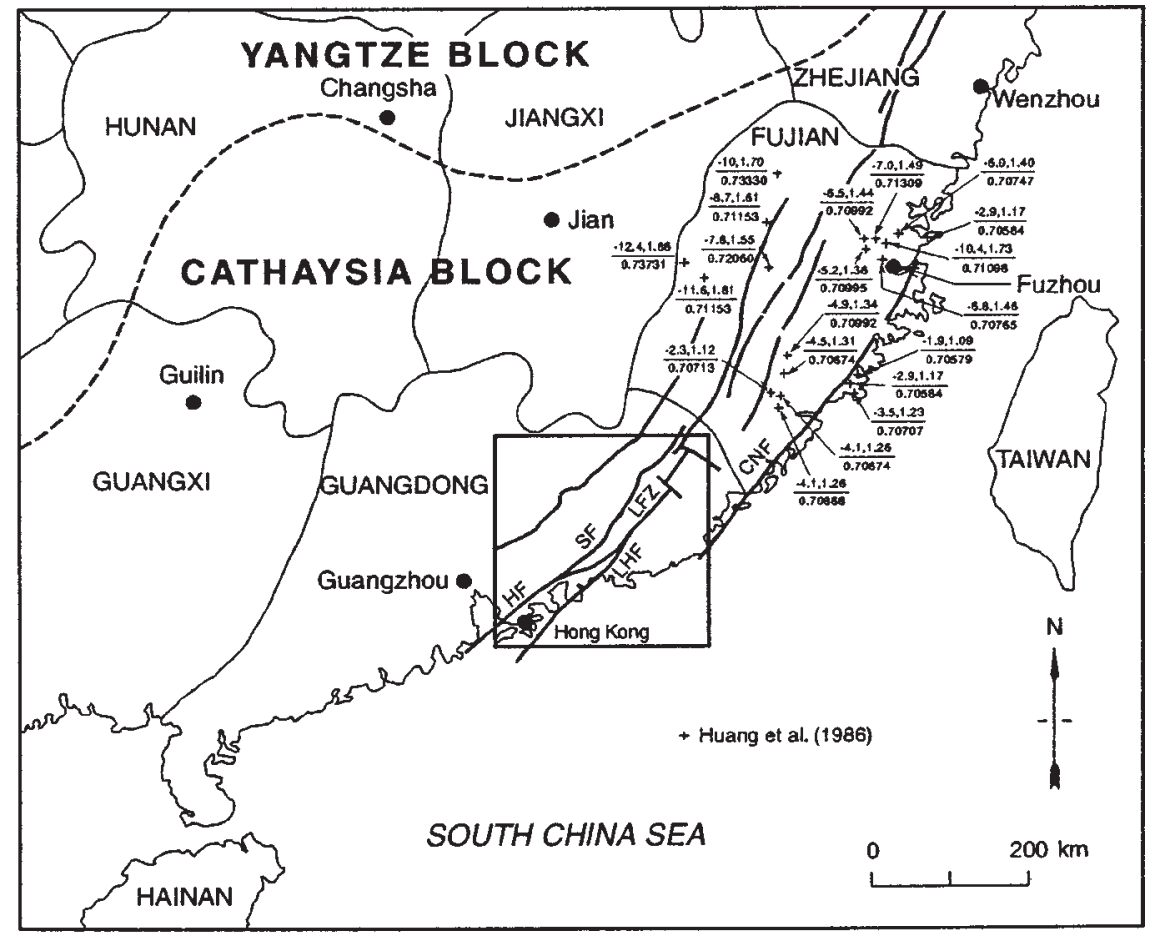

Figure 1 Generalised map of southeastern China showing the main tectonic elements and location of the study area. Isotope data from Huang et al. (1986).

CNF = Changle-Nan'ao Fault, HF = Heyuan Fault, LZF = Lianhuashan Fault Zone, LHF = Lishui-Haifeng Fault, SF= Shenzhen Fault. 
an increasing mantle influence. This is consistent with a widely held view that late Mesozoic intrusive activity was related to westerly subduction of the paleo-Pacific plate beneath the Asian continent; a tectonic event known as the Yanshanian Orogeny (190-80 Ma, Jahn et al., 1976; Yang et al., 1986). Somewhat more controversial has been the suggestion by Huang et al. (1986) that the boundary between the inland and central zones approximates the eastern limit of Precambrian crystalline basement. This interpretation has been challenged by Gilder et al. (1995) who argued that the published mean depleted-mantle $\left(\mathrm{T}_{\mathrm{DM}}\right)$ model ages from the region agree within error $(1 \sigma)$, thereby implying that the basement materials are isotopically homogeneous. Variations in isotopic signatures from inland areas to the coast are inferred by these authors to be controlled by late Mesozoic subduction processes.

A characteristic feature of the Cathaysia Block is the presence of several large-scale NNE-trending faults. These are represented by ductile shear zones and are commonly associated with small, faultbounded Cretaceous-Tertiary depositional basins. Two of these major faults have been considered as surface expressions of deepseated sutures: the Changle-Nan' ao Fault separating metamorphosed early Paleozoic volcanic arc assemblages in the east from the Mesozoic igneous province in the west (Guo et al., 1989; Gao and Huang, 1991), and the Lianhuashan Fault Zone (Chen, 1987) which parallels the continental margin from just south of Shanghai to Hong Kong (Figure 2). Recent isotopic evidence suggests that these faults may coincide with deep crustal boundaries. For example, Zhou et al. (1996) position a deep crustal boundary between the central and coastal zones of Huang et al. (1986) which is coincident with the
Changl-Nan'ao Fault, whereas Pei and Hong (1995) define a 0.708 $\mathrm{Sr}_{\mathrm{i}}$ isoline extending from Zhejiang, through Fujian to eastern Guangdong, which coincides with the Heyuan Fault. In a Nd-Sr isotope study of granites in the Hong Kong region, Darbyshire and Sewell (1997) have suggested that the NNE-trending Lianhuashan Fault Zone (LFZ) may also mark an important deep crustal boundary. This $30 \mathrm{~km}$-wide zone is bounded by two major NNE-trending faults: the Shenzhen Fault in the north and the Lishui-Haifeng Fault in the south. Granites in the northwestern part of Hong Kong are characterised by $\varepsilon_{\mathrm{Nd}}(\mathrm{T})<-9, \mathrm{~T}_{\mathrm{DM}}$ between 1.67 and $2.02 \mathrm{Ga}$, and ${ }^{87} \mathrm{Sr} /{ }^{86} \mathrm{Sr}_{\mathrm{i}}>0.710$, whereas in the southeast they have $\varepsilon_{\mathrm{Nd}}(\mathrm{T})$ between -5.5 and $-6.5, \mathrm{~T}_{\mathrm{DM}}$ between 1.39 and $1.47 \mathrm{Ga}$ and ${ }^{87} \mathrm{Sr} /{ }^{86} \mathrm{Sr}_{\mathrm{i}}$ $0.7071-0.7109$. The variation in isotopic signatures and $\mathrm{T}_{\mathrm{DM}}$ model ages reflects the interaction of mantle-derived melts with two distinct crustal sources. Paleoproterozoic and Mesoproterozoic crustal signatures in the granites have been recently confirmed by zircon inheritance studies (Davis et al., 1997). The oldest precise upper intercept age of $2714 \pm 4 \mathrm{Ma}$ from inherited components suggests that an Archean contribution cannot be entirely excluded. New geophysical evidence (Fletcher et al., 1997) supports the presence of a NNE-trending deep crustal discontinuity through the Hong Kong region.

The available data suggest that the crustal basement in SE China is isotopically heterogeneous and that major NNE-trending faults may delineate important tectonic boundaries. We further investigate these hypotheses by presenting the results of a $\mathrm{Nd}$ and $\mathrm{Sr}$ isotope transect across major NNE-trending fault zones in eastern Guangdong.

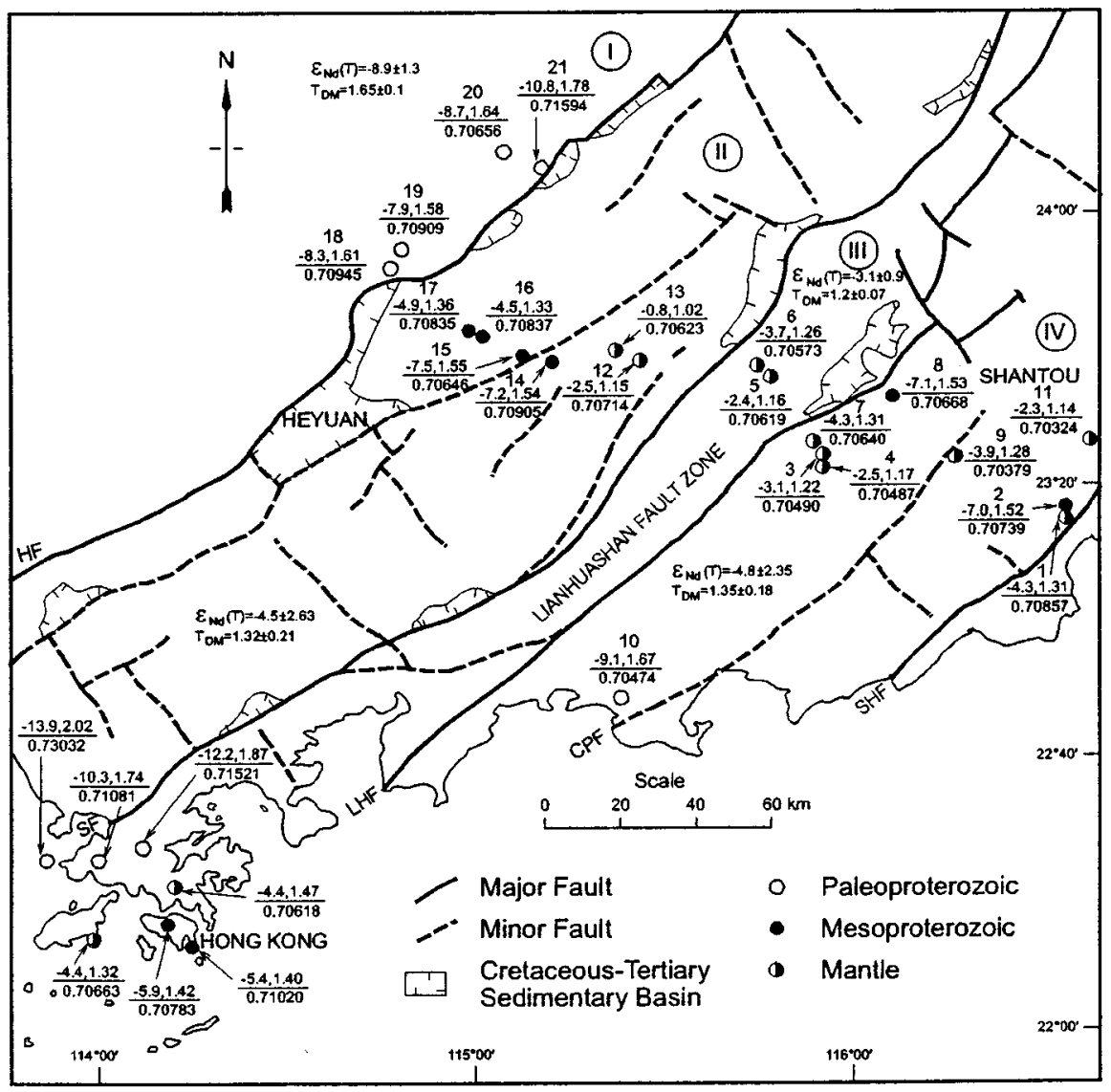

Figure 2 Simplified basement terrane and structural map of eastern Guangdong Province showing the location of sample sites, distribution of Paleoproterozoic-and Mesoproterozoicdominated crustal domains, distribution of Cretaceous-Tertiary sedimentary basins, zones of mantle-influenced crust, and location of major deep fault systems. Circled numbers refer to the four main structural zones for which averaged values of $T_{D M}$ and $\varepsilon_{N d}(T)$ are given. Data for Hong Kong from Darbyshire and Sewell (1997). Reference numbers for samples sites as for Table 1. CPF=Chao'an-Puning Fault, SHF=Shantou-Heilei Fault.

\section{Eastern Guangdong traverse}

Mesozoic plutonic rocks in SE China belong to a broad $(400 \mathrm{~km})$ NE-trending belt of intrusives comprising dominantly I-type granites, although A-type granites have been reported from the coastal areas (e.g., Martin et al., 1991, 1994; Charoy and Raimbault, 1994). The granitoids are generally assigned to five main Yanshanian episodes: $195 \pm 5$ $\mathrm{Ma}, 170 \pm 5 \mathrm{Ma}, 155 \pm 5 \mathrm{Ma}, 137 \pm 5 \mathrm{Ma}$ and $100 \pm 5$ Ma (BGMRGP, 1988). High precision $\mathrm{U}-\mathrm{Pb}$ zircon age-dating of granitic rocks in Hong Kong (Davis et al., 1997) has revealed four principal Middle Jurassic to Early Cretaceous magmatic events in southern Guangdong: $164.6 \pm 0.2 \mathrm{Ma}, 146.6 \pm 0.2$ $\mathrm{Ma}, 142.8 \pm 0.2 \mathrm{Ma}$ and $140.8 \pm 0.2 \mathrm{Ma}$. These ages, together with whole-rock geochemistry (Sewell and Campbell, 1997), provide a useful framework for calibrating the data from eastern Guangdong, particularly where precise ages of middle Yanshanian granites are unknown (see below).

Twenty-one granite samples from four structural zones were collected across a 200 $\mathrm{km}$ transect beginning west of the Heyuan Fault and extending to east of the Chao'anPuning Fault (Figure 2). The samples were analyzed for major and trace elements, and $\mathrm{Nd}$ and $\mathrm{Sr}$ isotopes. Isotopic data are presented in Table 1.

$\varepsilon_{\mathrm{Nd}}(\mathrm{T}),{ }^{87} \mathrm{Sr} /{ }^{86} \mathrm{Sr}_{\mathrm{i}}$ values and $\mathrm{T}_{\mathrm{DM}}$ have been calculated according to the method described in Darbyshire and Sewell (1997). This involves using a $\mathrm{Sm} / \mathrm{Nd}$ ratio which is dependent on crustal age. Where possible, 
Table $1 \mathrm{Rb}$-Sr and Sm-Nd data

\begin{tabular}{|c|c|c|c|c|c|c|c|c|c|c|c|c|c|c|c|c|c|}
\hline Zone & Description & $\begin{array}{l}\text { Ref. } \\
\text { No. }\end{array}$ & $\begin{array}{c}\text { Sample } \\
\text { No. }\end{array}$ & $\begin{array}{l}\text { Lat. } \\
{ }^{\circ} \mathbf{N}\end{array}$ & $\begin{array}{l}\text { Long. } \\
{ }^{\circ} \mathbf{E}\end{array}$ & $\begin{array}{l}\text { Age } \\
\text { (Ma) }\end{array}$ & $\begin{array}{c}\mathbf{R b} \\
(\mathbf{p p m})\end{array}$ & $\begin{array}{c}\mathrm{Sr} \\
(\mathrm{ppm})\end{array}$ & $\frac{{ }^{87} \mathrm{Rb}}{{ }^{86} \mathrm{Sr}}$ & $\frac{{ }^{87} \mathrm{Sr}}{{ }^{86} \mathrm{Sr}}$ & $\begin{array}{c}\text { Sm } \\
(\mathrm{ppm})\end{array}$ & $\begin{array}{c}\text { Nd } \\
(p p m)\end{array}$ & $\frac{\frac{147}{\mathrm{Sm}}}{{ }^{144} \mathrm{Nd}}$ & $\frac{\frac{143}{N d}}{{ }^{144} \mathrm{Nd}}$ & $\begin{array}{l}\varepsilon_{\mathrm{Nd}} \\
(\mathrm{T})\end{array}$ & ${ }^{{ }^{87} \mathrm{Sr}} \mathrm{Sr}$ & $\begin{array}{l}T_{\mathrm{DM}} \\
(\mathbf{G a})\end{array}$ \\
\hline$I$ & Biotite Granite & 18 & $\mathrm{X} 167$ & $23^{\circ} 52^{\prime}$ & $114^{\circ} 47$ & 164 & 378 & 83 & 13.15 & 0.74011 & 7.50 & 40.54 & 0.1119 & 0.51212 & -8.3 & 0.70945 & 1.61 \\
\hline I & Biotite Granite & 19 & $X 168$ & $23^{\circ} 55^{\prime}$ & $114^{\circ} 49^{\prime}$ & $157^{b}$ & 556 & 70 & 23.13 & 0.76072 & 7.92 & 35.14 & 0.1363 & 0.51217 & -7.9 & 0.70909 & 1.58 \\
\hline I & Biotite Granite & 20 & $\mathrm{X} 169$ & $24^{\circ} 08^{\prime}$ & $115^{\circ} 02^{\prime}$ & 164 & 425 & 65 & 18.86 & 0.75053 & 9.13 & 37.85 & 0.1458 & 0.51214 & -8.7 & 0.70656 & 1.64 \\
\hline 1 & Biotite Granite & 21 & $\mathrm{X} 170$ & $24^{\circ} 06^{\prime}$ & $115^{\circ} 12^{\prime}$ & 164 & 263 & 579 & 1.317 & 0.71901 & 13.2 & 81.11 & 0.0985 & 0.51198 & -10.8 & 0.71594 & 1.78 \\
\hline II & Microgranite & 16 & $\mathrm{X} 165$ & $23^{\circ} 41^{\prime}$ & $115^{\circ} 01^{\prime}$ & $148^{a}$ & 326 & 112 & 8.42 & 0.72607 & 3.82 & 14.72 & 0.1569 & 0.51237 & -4.5 & 0.70837 & 1.33 \\
\hline II & Biotite Granite & 17 & X166 & $23^{\circ} 42^{\prime}$ & $115^{\circ} 00^{\prime}$ & $148^{a}$ & 295 & 193 & 4.43 & 0.71768 & 3.61 & 15.55 & 0.1405 & 0.51233 & -4.9 & 0.70835 & 1.36 \\
\hline II & Biotite Granite & 12 & $X 161$ & $23^{\circ} 38^{\prime}$ & $115^{\circ} 25^{\prime}$ & $120^{\circ}$ & 257 & 79 & 13.06 & 0.72942 & 14.2 & 81.89 & 0.1046 & 0.51244 & -2.5 & 0.70714 & 1.15 \\
\hline II & Biotite Granite & 13 & $\mathrm{X} 162$ & $23^{\circ} 4 \mathrm{l}^{\prime}$ & $115^{\circ} 4 \mathrm{I}^{\prime}$ & $120^{\mathrm{a}}$ & 518 & 22 & 67.65 & 0.82161 & 4.28 & 23.02 & 0.1125 & 0.51253 & -0.8 & 0.70623 & 1.02 \\
\hline II & Granodiorite & 14 & $\mathrm{X} 163$ & $23^{\circ} 38^{\prime}$ & $115^{\circ} 12$ & $164^{b}$ & 201 & 228 & 2.55 & 0.71500 & 5.01 & 24.74 & 0.1226 & 0.51219 & -7.2 & 0.70905 & 1.54 \\
\hline III & Biotite Granite & 15 & X164 & $23^{\circ} 40^{\prime}$ & $115^{\circ} 10^{\circ}$ & $148^{a}$ & 383 & 35 & 31.98 & 0.77373 & 5.30 & 19.68 & 0.1628 & 0.51222 & -7.5 & 0.70646 & 1.55 \\
\hline III & Microdiorite & 5 & $X 152$ & $23^{\circ} 35^{\prime}$ & $115^{\circ} 42^{\prime}$ & 142 & 42 & 593 & 0.203 & 0.70660 & 7.09 & 37.02 & 0.1158 & 0.51244 & -2.4 & 0.70619 & 1.16 \\
\hline IV & Qtz Monzonite & 6 & $\mathrm{X} 155$ & $23^{\circ} 36^{\prime}$ & $115^{\circ} 41^{\prime}$ & $142^{b}$ & 162 & 301 & 1.555 & 0.70887 & 11.2 & 61.23 & 0.1107 & 0.51237 & -3.7 & 0.70573 & 1.26 \\
\hline IV & Biotite Granite & 3 & $\mathrm{X} 150$ & $23^{\circ} 23^{\prime}$ & $115^{\circ} 55^{\prime}$ & 142 & 241 & 194 & 3.60 & 0.71218 & 6.11 & 36.36 & 0.1015 & 0.51239 & -3.1 & 0.70490 & 1.22 \\
\hline IV & Biotite Granite & 4 & $\mathrm{X} 151$ & $23^{\circ} 23^{\prime}$ & $115^{\circ} 55^{\prime}$ & 142 & 259 & 184 & 4.07 & 0.71308 & 6.56 & 35.52 & 0.1116 & 0.51243 & -2.5 & 0.70487 & 1.17 \\
\hline IV & Biotite Granite & 7 & X156 & $23^{\circ} 2 c$ & $115^{\circ} 51^{\prime}$ & 142 & 243 & 210 & 3.35 & 0.71316 & 7.56 & 40.08 & 0.1140 & 0.51234 & -4.3 & 0.70640 & 1.31 \\
\hline IV & Biotite Granite & 8 & $\times 157$ & $23^{\circ} 34^{\prime}$ & $116^{\circ} 03^{\prime}$ & 164 & 179 & 118 & 4.38 & 0.71689 & 6.99 & 38.67 & 0.1093 & 0.51218 & -7.1 & 0.70668 & 1.53 \\
\hline IV & Biotite Granite & 10 & X159 & $22^{\circ} 48^{\prime}$ & $115^{\circ} 21^{\prime}$ & 164 & 339 & 58 & 16.93 & 0.74421 & 7.22 & 33.38 & 0.1307 & 0.51210 & -9.1 & 0.70474 & 1.67 \\
\hline IV & Quartz Porphyry & 1 & XI48 & $23^{\circ} 16^{\prime}$ & $116^{\circ} 33^{\prime}$ & 142 & 278 & 47 & 17.12 & 0.74312 & 5.72 & 15.73 & 0.2197 & 0.51244 & -4.3 & 0.70857 & 1.31 \\
\hline IV & Biotite Granite & 2 & X149 & $23^{\circ} 16^{\prime}$ & $116^{\circ} 33^{\prime}$ & 164 & 264 & 191 & 4.00 & 0.71671 & 8.58 & 42.76 & 0.1213 & 0.51220 & -7.0 & 0.70739 & 1.52 \\
\hline IV & Biotite Granite & 9 & X158 & $23^{\circ} 24^{\prime}$ & $116^{\circ} 15^{\prime}$ & 142 & 289 & 115 & 7.27 & 0.71847 & 7.66 & 29.90 & 0.1548 & 0.51240 & -3.9 & 0.70379 & 1.28 \\
\hline IV & Biotite Granite & 11 & $\mathrm{X} 160$ & $23^{\circ} 25^{\prime}$ & $116^{\circ} 37^{\prime}$ & $130^{a}$ & 203 & 124 & 4.74 & 0.71200 & 3.79 & 19.85 & 0.1155 & 0.51245 & -2.3 & 0.70324 & 1.14 \\
\hline
\end{tabular}

Notes: $1 \wedge$-Ages estimated according to geoehemical comparison with Hong Kong data unless otherwise indicated.

$2 \varepsilon_{\mathrm{Nd}}$ calculated relative to a chondritic reservoir with ${ }^{143} \mathrm{Nd} /{ }^{144} \mathrm{Nd}$ of 0.512638 and ${ }^{147} \mathrm{Sm} /{ }^{144} \mathrm{Nd}$ of 0.1967 .

$3 \mathrm{~T}_{\mathrm{DM}} \mathrm{Nd}$ model ages calculated according to a 2-stage model (after Borg, et al., 1990; DePaolo, et al., 1991).

4 Sample ratios adjusted to $\mathrm{Nd}$ and $\mathrm{Sr}$ standards run with each batch of measurements (La Jolla Nd=0.511858, NBS987 Sr=0.710251).

$5^{\text {a }}$-BGMRGP data (1988).

$6^{\mathrm{b}}$-HKU Unpublished data.

crustal ages for the granites have been assigned according to published radiometric ages in the Chinese literature. However, where these data are not available, intrusive ages are based on correlation with the Hong Kong data.

On a $\mathrm{TiO}_{2}$ versus $\mathrm{Zr}$ diagram (Figure 3), the analyzed middle Yanshanian samples from eastern Guangdong generally fall into two age categories defined by the Hong Kong data: $c .164$ Ma and $c .142$ $\mathrm{Ma}$. The $\mathrm{TiO}_{2}$ versus $\mathrm{Zr}$ diagram has been found to be an extremely useful plot for discriminating the major episodes of Middle Jurassic to Early Cretaceous magmatism in Hong Kong (Campbell \& Sewell, 1997). Concentrations of $\mathrm{Zr}$ and $\mathrm{Ti}$ are abundant in the analyzed samples and both elements have low susceptibility to mobility during alteration. Each group of volcanic and plutonic rocks has a characteristic $\mathrm{Zr} / \mathrm{TiO}_{2}$ ratio, and the general pattern of magmatic evolution is for the least-evolved compositions of each group to become more $\mathrm{Zr}$-enriched and $\mathrm{TiO}_{2}$-depleted with time. The variation in the initial $\mathrm{Zr} / \mathrm{TiO}_{2}$ ratios of each group is considered to reflect heterogeneities in the source region. Separate batches of magma generated in the Hong Kong region at 164-159 Ma, $146 \mathrm{Ma}, 142 \mathrm{Ma}$ and 140 $\mathrm{Ma}$ are thought to have been derived from variable degrees of partial melting of crustal material involving a mantle-derived component (Sewell \& Campbell, 1997).

As an independent check on the reliability of using the $\mathrm{TiO}_{2}$ versus $\mathrm{Zr}$ plot to infer the intrusive ages of granites in eastern Guangdong Province, three samples from separate structural zones were dated by $\mathrm{U}-\mathrm{Pb}$ single zircon techniques (HKU, unpublished data). These revealed ages of $164.2 \pm 0.4 \mathrm{Ma}, 156.9 \pm 0.4 \mathrm{Ma}$ and $141.8 \pm$ $0.4 \mathrm{Ma}$ in general accord with the Hong Kong groupings, although there is evidence for slight regional variation in the timing of magmatic activity. As with the Hong Kong data (Davis et al., 1997), Pre- cambrian inheritance was also found to affect the ages of granitoids in eastern Guangdong, indicating the presence of late Archean and Proterozoic components in the source regions of these magmas.

\section{Isotope results}

Averaged values for $\varepsilon_{\mathrm{Nd}}, \mathrm{T}_{\mathrm{DM}}$ and ${ }^{87} \mathrm{Sr} /{ }^{86} \mathrm{Sr}_{\mathrm{i}}$ from each of the four zones are shown on Figure 2. Granites from Zone I west of the Heyuan Fault are all of middle Yanshanian age. On a $\mathrm{TiO}_{2}$ versus $\mathrm{Zr}$ diagram, they plot in the field for Hong Kong granites dated at 164 Ma (Figure 3). $\varepsilon_{\mathrm{Nd}}(\mathrm{T})$ values vary between -7.9 and -10.8 , whereas ${ }^{87} \mathrm{Sr} /{ }^{86} \mathrm{Sr}_{\mathrm{i}}$ lie between 0.70656 and 0.71594 and $\mathrm{T}_{\mathrm{DM}}$ are in the range 1.58 to $1.78 \mathrm{Ga}$. Six granite samples from Zone II vary from Late Jurassic (148 Ma) to Early Cretaceous (120 Ma) age and show markedly higher $\varepsilon_{\mathrm{Nd}}$ values $(-7.5$ to -0.8$)$ than Zone I, along with lower overall initial $\mathrm{Sr}$ ratios (0.70905 to 0.70623), and lower depleted-mantle model ages ( 1.55 to $1.02 \mathrm{Ga}$ ). Two granite samples from Zone III between the Shenzhen and Lishui-Haifeng faults have distinctly lower $\varepsilon_{\mathrm{Nd}}(\mathrm{T})(-3.7$ to -2.4$)$ and $\mathrm{T}_{\mathrm{DM}}(1.26$ to $1.16 \mathrm{Ga})$. On a $\mathrm{TiO}_{2}$ versus $\mathrm{Zr}$ diagram, these granites plot with Hong Kong granites dated at $142 \mathrm{Ma}$ (Figure 3). Zone III corresponds to the Lianhuashan Fault Zone from which highly variable isotope values are known (Darbyshire and Sewell, 1997). Granites in Zone IV between the Lishui-Haifeng and Shantou-Heilei faults have $\varepsilon_{\mathrm{Nd}}(\mathrm{T})$ values in the range -9.1 to -2.3 , initial $\mathrm{Sr}$ ratios between 0.70857 and 0.70324 , and $\mathrm{T}_{\mathrm{DM}}$ between 1.67 and 1.14. On a $\mathrm{TiO}_{2}$ versus $\mathrm{Zr}$ diagram, these granites plot with Hong Kong granites which have been dated at 164 Ma and $142 \mathrm{Ma}$ 


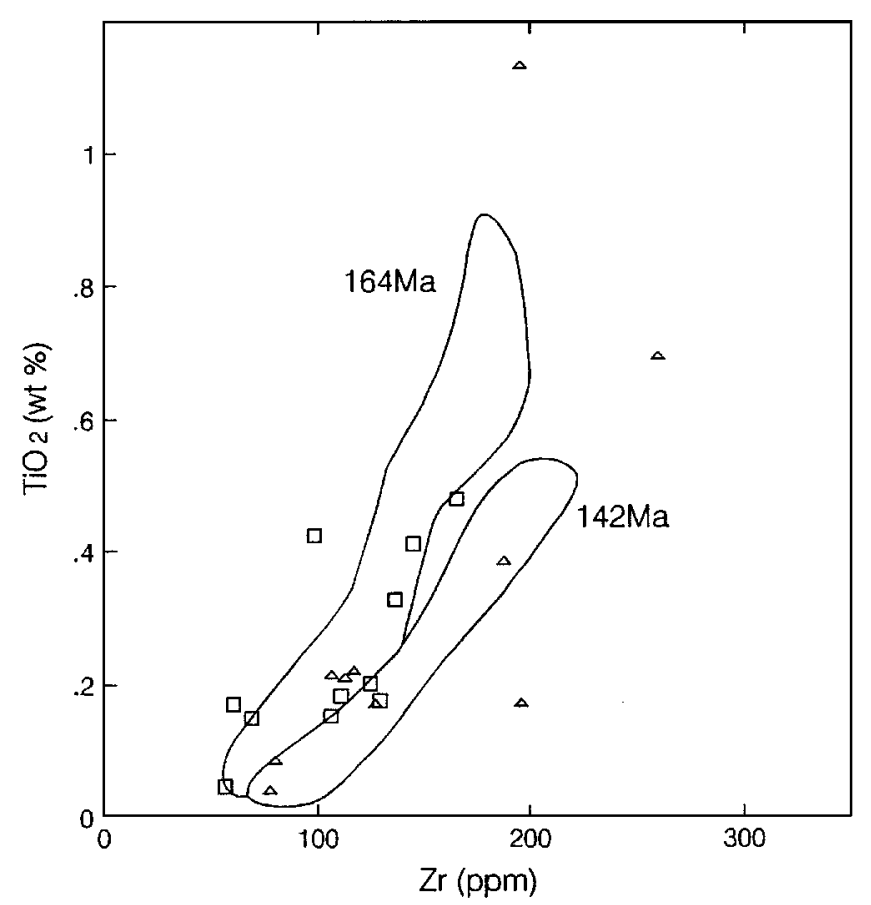

Figure $3 \mathrm{TiO}_{2}$ versus $\mathrm{Zr}$ diagram for analyzed samples showing the field boundaries for Middle Jurassic and Lower Cretaceous granites from Hong Kong. Open square=Jurassic granites, Open triangles $=$ Cretaceous granites.

\section{Discussion}

The NE-trending isotopic zonation of the crustal basement of SE China suggests that at least four predominantly Paleoproterozoic and Mesoproterozoic crustal domains occur beneath the Neoproterozoic and Phanerozoic cover sequences. The boundaries to these isotopic zones are coincident with major faults that can be traced throughout the coastal provinces. The isotopic signatures and $\mathrm{T}_{\mathrm{DM}}$ model ages of Zone I to the northwest of the Heyuan Fault, are compatible with a model of crustal anatexis involving a predominantly Paleoproterozoic protolith but with significant input of Mesoproterozoic crust to these melts. This crustal basement probably forms part of the Paleoproterozoic core to the Cathaysia Block. To the southeast, Zone II lies between the Heyuan and Shenzhen faults. This zone is between 60 and $90 \mathrm{~km}$ wide and is underlain by predominantly Mesoproterozoic crust although a Paleoproterozoic component cannot be ruled out. However, along its southeastern boundary the Mesozoic granites have strongly mantle-influenced signatures. Zone III is coincident with the Lianhuashan Fault Zone which is up to $30 \mathrm{~km}$ wide and bounded by the Shenzhen and Haifeng faults. The isotopic zonation within the Lianhuashan Fault Zone is well-documented in Hong Kong (Darbyshire and Sewell, 1997), with predominantly Paleoproterozoic signatures to the northwest and more mafic Mesoproterozoic components towards the southeast. In addition, mantle-derived magmas define a narrow SE-trending belt in the central part of the fault zone (Figure 3). Similar mantle-influenced isotopic values have been found in the central part of the Lianhuashan Fault Zone along the Guangdong traverse. Zone IV displays an average Mesoproterozoic signature with minimal mantle influence. However, isolated samples from Zone IV have produced both Paleoproterozoic and mantle isotopic values.

No general trend of increasing mantle component towards the southeast, as suggested by Gilder et al. (1995), has been identified, either in the detailed survey of Hong Kong or in the Guangdong traverse. Rather, the mantle-influenced samples occur in narrow belts, some of which lie close to the main zonal boundaries. The lateral continuity of mantle-derived magmas within the Lianhuashan Fault
Zone would strongly suggest the presence of a deep, SE-trending, crustal discontinuity. But it is still too early to identify the regional significance of other mantle-derived samples.

\section{Conclusions}

The isotopic signatures of the Mesozoic granites of southeastern China would strongly indicate that the Precambrian basement is heterogeneous and made up of a series of Paleoproterozoic- and Mesoproterozoic-dominated crustal domains interspersed with a few narrow belts displaying mantle-derived characteristics. However, detailed sampling in Hong Kong has shown that within these domains the truly isotopically homogeneous subzones may be as narrow as $20 \mathrm{~km}$. Thus, it is probable that the Paleoproterozoic signatures yielded by some samples in Zones II and IV, which are characterised by Mesoproterozoic-derived magmas, relate to narrow tectonic slivers of Paleoproterozoic crust. Although it would be tempting to designate the four isotopic zones as tectonic terranes, the current data would indicate that the composition of the crust is much more complicated, and isotopically homogeneous segments may be extremely narrow.

The nature of the zonal boundaries is still uncertain, but they are coincident with major fault zones in the cover sequences. It is postulated that the boundaries developed in the crust during the Mesoproterozoic and could represent subduction zones, major strike slip faults, or the margins of greenstone belts. However, once formed, they largely controlled the geological development of SE China throughout the Phanerozoic.

\section{Acknowledgements}

We thank X. H. Li for helpful reviews of earlier drafts, and we are grateful for comments made by an anonymous referee. This project was supported by a Hong Kong RGC Grant to LSC and RJS and a HKU CRCG grant to LSC. This paper is published with the approval of the Director of Civil Engineering, Hong Kong SAR Government.

\section{References}

Borg, S. G., DePaolo, D. J., and Smith, B. M., 1990, Isotopic structure and tectonics of the central Transantarctic mountains: Journal of Geophysical Research, 95, 6647-6667.

Bureau of Geology and Mineral Resources of Guangdong Province, 1988 , Regional Geology of Guangdong Province: Geological Memoirs Series, v. 1, no. 9. Geological Publishing House, Beijing, China.

Campbell, S. D. G., and Sewell, R. J., 1997, Structural control and tectonic setting of Mesozoic volcanism in Hong Kong. Journal of the Geological Society, London, v. 154, pp. 1039-1052.

Chen, T. G., 1987, Basic features of the Lianhuashan Fault Zone in Hong Kong and Shenzhen area: Journal of Guangdong Geology, v. 2, pp. 57-68.

Chen, J. F.,. and Jahn, B. M., 1998, Crustal evolution of southeastern China: Nd and Sr isotopic evidence: Tectonophysics, v. 284, pp. 101-133.

Darbyshire, D. P. F., and Sewell, R. J., 1997, Nd and Sr isotope geochemistry of plutonic rocks from Hong Kong: Implications for granite petrogenesis, regional structure and crustal evolution: Chemical Geology, v. 143, pp. 81-93.

Davis, D. W., Sewell, R. J., and Campbell, S. D. G., 1997, U-Pb dating of Mesozoic igneous rocks from Hong Kong: Journal of the Geological Society, London, v. 154, pp. 1067-1076.

DePaolo, D. J., Linn, A. M., Schubert, G. 1991. The continental crustal age distribution: methods of determining mantle separation ages from $\mathrm{Sm}-\mathrm{Nd}$ isotopic data and application to the southwestern United States: Journal of Geophysical Research, 96, 2071-2088.

Fletcher, C. J. N., Campbell, S. D. G., Busby, J. P., Carruthers, R. M., and Lai, K. W., 1997, Regional tectonic setting of Hong Kong: implications of new gravity models: Journal of the Geological Society, London, v. 154, pp. 1021-1030. 
Gao, T. J., and Huang, H., 1991, Two important terrane boundaries in the southeast coastal region: Geology of Fujian, v. 10, pp. 1-15.

Gilder, S. A., Gill, J. A., Coe, R. S., Zhao, X., Liu, Z., Wang, G., Yuan, K., Liu, W., Kuang, G., and Wu, H., 1996, Isotopic and paleomagnetic constraints on the Mesozoic tectonic evolution of south China: Journal of Geophysical Research, v. 101, pp. 16,137-16,154.

Guo, L. Z., Shi, Y. S., Lu, H. F., Ma, R. S., and Dong, H. G., 1989, The preDevonian tectonic patterns and evolution of South China: Journal of Southeast Asian Earth Sciences, v. 3, pp. 87-93.

Hsü, K. J., Shu, S., Jiliang, L., Haihong, C., Haipo, P., and Sengor, A. M. C., 1988, Mesozoic overthrust tectonics in south China: Geology, v. 16, pp. $418-421$.

Hsü, K. J., Jiliang, L., Qingchen, W., Shu, S., and Sengor, A. M. C., 1990, Tectonics of South China: Key to understanding West Pacific geology: Tectonophysics, v. 183, pp. 9-39.

Huang, X., Sun, S. H., DePaolo, D. J., and Wu, K. L., 1986, Nd-Sr isotope study of Cretaceous magmatic rocks from Fujian Province: Acta Petrologica Sinica, v. 2, pp. 50-63 (in Chinese, with English abstract).

Huang, X., and DePaolo, D. J., 1989, Study of sources of Paleozoic granitoids and the basement of south China by means of Nd-Sr isotopes: Acta Petrologica Sinica, v. 1, pp. 28-36.

Jahn, B. M., Chen, P. Y., and Yen, T. P., 1976, Rb-Sr ages of granitic rocks in southeastern China and their tectonic significance: Bulletin of the Geological Society of America, v. 86, pp. 763-776.

Li, X. H., Zhao, Z., Gui, X, and Yu, J. L. 1992. Sm-Nd and zircon U-Pb isotopic constraints on the age of formation of the Precambrian crust in Southeast China. Chinese Journal of Geochemistry, v. 11, pp. 111-120.

$\mathrm{Li}, \mathrm{X}$. H. 1994. A comprehensive U-Pb, Sm-Nd, Rb-Sr and ${ }^{40} \mathrm{Ar}-{ }^{39} \mathrm{Ar}$ geochronological study on Guidong Granodiorite, southeast China: records of multiple tectonothermal events in a single pluton: Chemical Geology, v. 115, pp.283-295.

$\boldsymbol{R}$. J. Sewell is a mapping geologist with the Hong Kong Geological Survey, Hong Kong Special Administrative Region Government. He obtained his $P h D$ from the University of Canterbury, New Zealand in 1985, and prior to arriving in Hong Kong, worked for the New Zealand Geological Survey. His main interests for the past ten years have been the petrology, geochronology of Mesozoic volcanic and granitic rocks of the Hong Kong region. He has also contributed to studies on the environmental geochemistry of Hong Kong.
Li, X. H. 1997. Timing of the Cathaysia Block formation: Constraints from SHRIMP U-Pb zircon geochronology: Episodes, v. 20, pp 188-192.

Li, Z. X. 1998. Tectonic history of the major East Asia lithospheric blocks since the mid-Proterozoic - a synthesis. In: M. J. Flower, S.-L. Chung, T. Y. Lee, and C.-H. Lo eds, Mantle dynamics and plate interactions in East Asia. American Geophysical Union Geodynamic Series, v. 27, pp. 221-244.

Liu, X. and Fu, D. R., 1988, The sedimentary association and tectonic evolution of Meso-Cenozoic Basins in eastern China: Environmental Science Press of China, Beijing. 189 p.

Lu, H., Jia, D., Wang, Z., Guo, L., Shi, Y., and Zhang, Q., 1994, Tectonic evolution of the Dongshan terrane, Fujian Province, China: Journal of Southeast Asian Earth Sciences, v. 7, pp. 346-365.

Martin, H., Bonin, B., Capdevila, R., Didier, J., Jahn, B. M., Lameyre, J., Qui, Y., and Wang, Y., 1991, The Fuzhou granitic complex (SE China): petrology and geochemistry: Geochimica, v. 2, pp. 100-111.

Martin, H., Bonin, B., Capdevila, R., Jahn, B. M., Lameyre, J., and Wang, Y., 1994, The Kuiqi peralkaline granite complex (SE China): petrology and chemistry: Journal of Petrology, v. 35, pp. 983-1015.

Pei, R., and Hong, D., 1995, The granites of south China and their metallogeny: Episodes, v. 18, pp. 77-82

Sewell, R. J., and Campbell, S. D. G., 1997, Geochemistry of coeval Mesozoic plutonic and volcanic suites in Hong Kong: Journal of the Geological Society, London, v. 154, pp. 1053-1066.

Yang, Z., Cheng, Y., and Wang, H., 1986, The Geology of China: Oxford Monographs on Geology and Geophysics 3, Clarendon Press, Oxford.

Zhou, Z., Lao, Q., Chen, H., Ding, S., and Liao, Z., 1996, Early Mesozoic orogeny in Fujian, southeast China: in Hall, R., and Blundell, D., eds., Tectonic Evolution of Southeast Asia, Geological Society of London Special Publication 106, pp. 549-556.

C. J. N. Fletcher is currently Director of the Applied Geoscience Centre at the University of Hong Kong, and was Head of the Hong Kong Geological Survey for five years. He has undertaken geological mapping and research projects in Canada, United Kingdom and China, and has been part of technical development programme in Korea, Bolivia, Peru and Pakistan. His main interest at present is the application of geology to urban engineering projects.

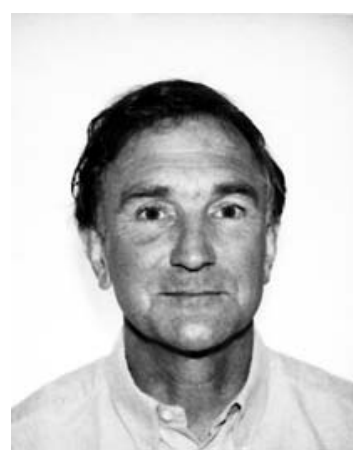

L. S. Chan is currently Associate Professor in the Department of Earth Sciences at the University of Hong Kong and Chair of Geological Society of Hong Kong. He received his doctorate degree at the University of California in 1984 and taught geology and geophysics at the University of Wisconsin-Eau Claire during 1984-1994. His current research is on urban geophysics, in particular application of geophysical methods to engineering and environmental studies, and the geology of Hong Kong and South China.

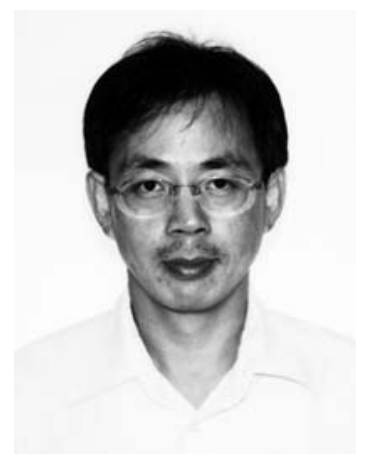

